CATALAN REVIEW

Catalan Review

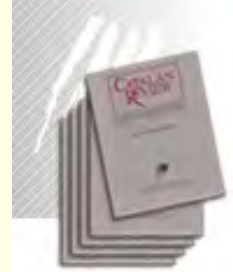

You are accessing the Digital Archive of the Catalan Review Journal.

By accessing and/or using this Digital Archive, you accept and agree to abide by the Terms and Conditions of Use available at http://www.nacs-

catalanstudies.org/catalan_review.html

Catalan Review is the premier international scholarly journal devoted to all aspects of Catalan culture. By Catalan culture is understood all manifestations of intellectual and artistic life produced in the Catalan language or in the geographical areas where Catalan is spoken. Catalan Review has been in publication since 1986.
NORTH

AMERICAN

CATALAN

SOCIETY
Esteu accedint a l'Arxiu Digital del Catalan Review

A l' accedir i / o utilitzar aquest Arxiu Digital, vostè accepta i es compromet a complir els termes i condicions d'ús disponibles a http://www.nacs-

catalanstudies.org/catalan review.html

Catalan Review és la primera revista internacional dedicada a tots els aspectes de la cultura catalana. Per la cultura catalana s'entén totes les manifestacions de la vida intel lectual i artística produïda en llengua catalana o en les zones geogràfiques on es parla català. Catalan Review es publica des de 1986.

\title{
Montserrat Roig's EI temps de les cireres: A Nostalgic Look at the Past
}

Andrew J. Deiser

Catalan Review, Vol. XX, (2006), p. 69-81 


\section{ABSTRACT}

In Postmodernism or, the Cultural Logic of Late Capitalism, Fredric Jameson speaks to the legitimacy of the claim that we have entered the postmodern era. $\mathrm{He}$ also notes, however, that cultural artifacts often contain elements of a previous social structure while, at the same time, revealing one in its early stages of development. In this article I argue that Montserrat Roig's r977 novel, El temps de les cireres, supports Jameson's premise. Through the motifs of photography and time, Roig not only chronicles some of the significant social changes took place in Barcelona during the 1960s and 1970s, she also conjures up the city's more remote past for an older generation that had been denied it, as well as for a younger generation that no longer recognized it. In so doing, her novel not only documents events leading up to Spain's transition to democracy, it also grapples with the broader historical transition from modernity to postmodernity in Spain.

In her biographical essay on Montserrat Roig, Geraldine Nichols asserts that Roig's "uncompromising commitment to explore the world of women and the world's impact on them makes her an especially interesting subject for feminist analysis" ("Montserrat Roig" 357). Indeed, several critics have explored Roig's fiction within a feminist framework. In "Historia del avance espacial de Barcelona y sus mujeres. Ideología y estética de la ciudad en Montserrat Roig," Christina Dupláa examines the relationship between Roig's female characters and the space of the city. In another study, "Montserrat Roig: Women, Genealogy, and Mother Tongue," Dupláa argues that Roig, despite her doubly marginalized status (352), was successful in establishing the role of women in Catalan history while also legitimizing her own "intellectual production" in Catalan (338). Emilie Bergmann, in "Mothers, Daughters, and the Mother Tongue: Martín Gaite's El cuarto de atrás and Roig's El temps de les cireres," discusses the relationship between the mother and daughter figures in Roig's El temps de les cireres. In addition, Bergmann explores the significance of Roig's decision to write in Catalan, arguing that it reflects the "gender relationships" portrayed in the novel (99). The nature of these relationships, in turn, Bergmann claims, underscores the silencing of women in a predominantly patriarchal Catalan society.

In contrast to these critics' feminist readings of Roig's novelistic 
production-and El temps de les cireres in particular-this article offers a socio-historical reading of this novel by focusing on the motifs of photography and time found therein. In the pages that follow, I will argue that these motifs serve not only to document some of the sweeping social changes that took place during the decade prior to publication of the novel in 1977 , but that they also address the broader historical shift from modernity to postmodernity in Catalan and, by extension, Spanish society.

El temps de les cireres (henceforth El temps) begins with Natàlia Miralpeix's return to Barcelona after a twelve-year absence due to an abortion that virtually ends an already strained relationship with her father. The characters that make up her family represent several generations of Catalans. Natàlia's grandparents, "el vell Miralpeix" and "la Mundeta vella," both of whom were born in the latter half of the nineteenth century, embody a generation whose formative years took place in the 1800 . There is also the generation represented by Natàlia's father and mother, Joan Miralpeix and Judit Claret, who were born prior to the Second Republic and are portrayed as having forsaken their ideological and political ideals in order to survive the postwar era. In addition, there is the generation personified by Natàlia, her brother, and his wife, Silvia, all of whom were born toward the end of the Civil War. Natàlia represents the youth who partook in the sexual revolution and student movement in 1960 Barcelona, whereas Lluís and Sílvia personify Barcelona's nous rics. ${ }^{\mathrm{I}}$ Finally, there is a fourth generation embodied in Màrius, the son of Lluís and Sílvia, who symbolizes the postwar generation in whom the historical memory of the war and its aftermath have all but been forgotten. Through the technique of flashback and the use of interior monologues and dialogues, the novel gives a psychological portrait of each generation's response to events involving the characters' personal lives and the historical and political events that shaped their lives.

In "Mothers, Daughters, and the Mother Tongue," Bergmann notes "the photographic perspective of description" in El temps (IO3), asserting that it creates distance between Natalia and the other characters, as well as between Natàlia and the culture she witnesses upon her return to Barcelona (103-06). Photography, in fact, becomes a motif in the novel performing several functions, one of which is to frame different scenes as if they were snapshots, or visual documents, of Catalan society at different moments in its history. In "La fotografía en la novela," Germán Gullón notes that photographs that appear in novels are images that are "literalizadas," and therefore "[e]l estilo y la 
lengua del autor se superponen, absorben la imagen en la tinta de las letras de imprenta, la transustancian. Examinar la imagen equivaldrá, en principio, a revisar el estilo [del autor]" (Io). It is with Gullón's observation in mind, then, that I will examine Roig's style and the language she employs in El temps in several passages where she either alludes to or refers directly to photography.

Commenting on a scene in the novel that portrays the student movement in Barcelona in 1962 , Bergmann asserts that it "is narrated in a style mimicking journalistic detail: who, where, when, how, in order to establish the innocence of the students..." and further explains that "the police claim that students were throwing rocks, but the narrator's meticulously detailed account of the actions of the students casts serious doubts upon that claim" (IO3). In this passage, Roig chronicles the Franco regime's repression of the Barcelona student movement. By weaving this real-life occurrence into the story line of the novel, she highlights the movement as a significant event during the lead up to Spain's transition from dictatorship to democracy following General Francisco Franco's death in 1975. In a similar way Roig documents the unprecedented number of immigrants who arrived in Catalunya during the Franco dictatorship. The immigrant working class in El temps is embodied in the family's maid, Encarna. Her name, which is related to the Spanish verb encarnar [to incarnate, to become flesh], suggests her symbolic role in the novel. The passage describing Encarna's wedding reception serves to underscore the phenomenon of mass immigration to Catalunya between 1950 and the early 1970 . The reception takes place at Encarna's sister's bar and opens with the description of a series of photos of the newlyweds and their relatives: "[L'Encarna] s'havia de fotografiar amb en Jaume i cada un dels parents: l'Encarna i en Jaume amb la Rosalia, el seu marit i els fills petits, l'Encarna i en Jaume amb el fillol de l'Encarna, l'Encarna i en Jaume amb un oncle vell d'en Jaume..." (174). The litany of names reinforces the notion of group solidarity among the fictional immigrants and reminds native Catalan readers of the presence of Barcelona's new immigrant population, which established itself as the city's new working class during the postwar era. Natàlia and Màrius, the only two native Catalans at the wedding, are the last to be photographed with the couple, thus underscoring their symbolic role as the autochthonous community's witness to the arrival of this new population. Feeling somewhat out of place, Natàlia and her nephew take in the wedding from a distance. At one point Natàlia asks Màrius if he is bored: "No, contestà el noi, això és un document humà" (I76). His reply reinforces the notion that the wedding scene is written as if it were a journalistic piece, with photos, serving to document a social event (Bergmann I04). Thus, not only does this scene function to 
document the phenomenon of immigration it also alludes to its consequences, in particular the change in Catalunya's linguistic landscape during the dictatorship and the ensuing linguistic debates that would dominate Catalan politics during the 1980 s and gos.

In addition to its role of documenting Barcelona's student movement of the 1960 and the mass influx of immigrants to the city, the motif of Photography in El temps also serves to recover the more remote past. Natàlia, having learned the art of photography during her years of exile, returns to Barcelona in order to bring into perspective not only the present but also the past. Metaphorically speaking, the object she views "as through a camera lens" is history: her personal history, her family's history, and Catalan history (Bergmann I03). Harmonia, Natàlia's art teacher prior to her departure, is the figure in the novel who serves as Natàlia's principal mentor, introducing her to aspects of Catalan culture, in particular to the works of Catalunya's great poets: Salvador Espriu, Pere Quart, Ausiàs March, Josep Carner, to name only four. In this way, Harmonia acquaints Natàlia with those aspects of her Catalan heritage of which she is ignorant. It is also interesting to note that Harmonia-in her desire to cultivate an appreciation for Catalan culture in Natàlia-emphasizes the Catalan Romanesque art of Taüll: "L'Harmonia parlà a les alumnes de l'art romànic català i les féu anar a Taüll” (33). The character Joaquim Benlloc in Terenci Moix's 1969 El dia que va morir Marilyn also makes reference to the Romanesque architecture in Taüll, likening it to a remnant of a golden age in Catalan culture. The cultural reference that Moix employed in his novel and which Roig then incorporated into her novel suggests a model for reconstructing Catalan identity that existed during the years prior to General Francisco Franco's death, and which survived beyond his death. By emphasizing Catalunya's Romanesque architecture, these authors, whether consciously or not, drew upon the permanence of these architectural forms as a metaphor for the solid foundation upon which Catalunya needed to rebuild its identity - an identity that had been virtually destroyed during the Franco dictatorship. Roig, in El temps, provides yet another way of appropriating images of the past in order to make a statement about Catalan national identity by utilizing the motif of photography. In her book titled On Pbotography, Susan Sontag explains that the "photograph offers a modern counterpart of that characteristically romantic architectural genre, the artificial ruin: the ruin which is created in order to deepen the historical character of a landscape, to make nature suggestive-suggestive of the past" (80). Thus, in addition to her mention of Taüll, Roig's visual snapshots of social phenomena that shaped Barcelona during the 1960 s and 1970 s reinforce the historical quality of the narrative in El temps. 
If El temps reflects the process by which Catalans began to recover their past in order to rebuild their identity in the postwar years, it also underscores the difficulties that underlay that process in an emerging postmodern era. Fredric Jameson, in Postmodernism or, the Cultural Logic of Late Capitalism, speaks to the legitimacy of the claim that we have entered the postmodern era but also notes that cultural artifacts often contain what Raymond Williams deemed "residual" elements of a previous social structure while, at the same time, revealing an "emerging" one (6). In light of Jameson's observations, it could be said that in writing El temps, Roig created a "residual" form of capitalist cultural production, to borrow the term from Williams, even though Spain had already entered the early stages of late capitalism. In other words, she produced a novel whose aesthetic more closely resembles that of the modernist novel than that of the postmodern novel. El temps' fragmented narrative due to its abundant use of flashbacks, the novel's focus on the highly individualistic style of Barcelona's modernista period, and Natàlia's self-awareness as an artist, all recall the hallmarks of the modernist novel. With the same photographiclike perspective the narrator in El temps uses to record the student protests of the 1960 (Bergmann 103) and the demographic changes that had taken place by the mid-I970s, Roig also conjures up the golden age of the industrial Catalan bourgeoisie: Barcelona's modernista era. It could be said, then, that the narrator's role vacillates between that of journalist and that of artist, and the narrator's subject matter, between social document and work of art, as the description in the novel alternates between an objective view of public spaces and events to a subjective view of private spaces and personal events.

In "The Link in Consciousness: Time and Community in Rodoreda's La Plaça del Diamant," Joan Ramon Resina discusses the temporal function of things in Rodoreda's La Plaça del Diamant (henceforth La Plaça): "Things are certainly time's harbingers, but not so much on account of their resistance to time as for the reason that they are marked by it. In this novel things age, they carry the patina of the period in which they appeared, and while persisting they suffer from the contrast with newer things that signal a new epoch" (235). Without much stretch of the imagination, we can apply Resina's observation concerning Rodoreda's La Plaça to Roig's El temps. For instance, when Natàlia arrives at the home of her aunt Patrícia, she is confronted with a host of objects that open a window on Barcelona's past:

Tot era igual que abans, la mateixa escala de marbre, la barana que recolzava cap a l'esquerra, la figura modernista de bronze que sostenia un globus, la gàbia de la portera, el sostre cromat, els agafadors daurats i lluents, els vidres esmerilats, la peça de ferro treballada per a treure el fang de les botes-quan els senyors de Barcelona ni somiaven amb els carrers asfalcats-, la llarga $i$ estreta 
catifa de color magrana una mica ratada per les vores... Tot era al seu lloc, els objectes polits, el silenci de l'escala, les olors, el marbre lluent encara que els esglaons eren una mica escantellats. (22)

Although the phrase "Tot era igual que abans" refers to the way Natàlia remembers the objects as they were when she was a child, it can also be understood on a figurative level as an allusion to a former Barcelona (22). Indeed, the objects described in the above passage "carry the patina," in Resina's words, of modernista Barcelona (235). Here, Natàlia herself serves as the lens through which the narrator focuses the description of the still objects, thus producing for readers the effect of a photographic image. However, in contrast to the journalistic perspective of the images portraying the student movement and Encarna's wedding, the photographic image in the passage above depicts a subjective perspective of a private space and the objects that occupy it.

It could also be said that the photographic-like perspective with which the narrator describes the interior of aunt Patricia's apartment building captures a moment in time that is static in nature-an observation that is highlighted by the fact that the objects in the above passage are enveloped in silence, as if the flow of time had been arrested. Sontag confirms the ability of the photograph to freeze reality and thus appear to halt the flow of time by asserting that "[p]hotographs are a way of imprisoning reality, understood as recalcitrant, inaccessible; of making it stand still" (I63). The arresting of time as a motif is, in fact, developed in conjunction with that of photography in El temps. For instance, in a symbolic gesture suggesting the cessation of time, the narrator intermittently focuses on clocks that have quit working. An example of this occurs when, in the middle of her description of the luxury items that fill Patricia's home, the narrator remarks, "el rellotge del besavi s'havia aturat" (27). The grandfather clock, thus, becomes a subtle but telling detail in the background of the narrator's description of objects that recall modernista Barcelona. On the one hand, it signals the end of a golden age for the Catalan bourgeoisie; on the other hand, by denoting the stoppage of time, it appears to be an attempt to safeguard the spirit of that era against the destructive effects of time.

In his essay, Proust in the Power of Photography, the photographer and journalist Gyula Halász Brassaï examines the influence of photography in Proust's writings. In the introduction to his essay, Brassai states: "I shall add that in his battle against Time... it was in photography, also born of an age-old longing to halt the moment, to wrest it from the flux of 'duree' in order to 'fix' it forever in a semblance of eternity, that Proust found his best ally" (xi). It is not by chance that I include Proust in my discussion of Roig's ability to 
weave together the motifs of time and photography in El temps. Like the protagonist in $\grave{A}$ la recherche du temps perd $u$ (henceforth $\grave{A}$ la recherche) who experiences a rush of memories upon biting into a magdaleine, Natalia's recollection of her past is triggered by her memory of a garden and a lemon tree from her childhood (Palerm 185). In addition, Roig herself makes two direct references to Proust in the novel. More significantly, however, it could be said that Roig's use of a photographic-like perspective to describe objects in El temps is reminiscent of a similar technique employed by Proust in $A$ la recherche. Throughout $\dot{A}$ la recherche, the narrator, like the one in El temps, produces snapshots of spaces by providing detailed descriptions of the objects that inhabit those spaces. In its treatment of photography and time, then, it could be said that El temps recalls Proust's $A$ la recherche in that $E$ l temps attempts to recover the past against the ravages of time.

A much more self-reflexive example of how the motifs of photography and time are woven together in El temps occurs during one of Natàlia's more pensive moments: "Potser per això vull fer fotografies, es deia, perquè és una manera de violar el temps i no pemetre que ell et violi a tu" (193). Natàlia's wish to halt the flow of time is a response to the significant changes she observes upon her return to Barcelona. In addition to her witness of the shift in Barcelona's demographics and the demoralizing effect of the Franco regime's repressive policies, she also experiences the dizzying effects of an accelerated modernization taking place in Barcelona in the early 1970 (Palerm 188). In effect, Natàlia confronts not just one but two formidable obstacles in her attempt to recover the past: a repressive regime that manipulates history and the disorienting effects of the present due to the emerging postmodern era in Spain. In order for her to overcome these obstacles, the narrator-whose voice is often filtered through the thoughts of Natàlia-preserves the past and documents the present through a photographic-like description of events and objects in the novel (Bergmann 103). The treatment of the past and the present plays itself out on another level in El temps, however, in the way in which each of the main characters confronts his or her own past and present. In "Memory, Oblivion and Space," Carmiña Palerm states that "[t]he characters in the novel can be divided into two categories: those that want to remember and those that need to forget the traumatic past in order to survive the present" (184). Among the former she places Natàlia and among the latter, Natàlia's father. Upon closer examination, however, this binary opposition breaks down between Natàlia and her father. Certainly, it can be said that Natàlia comes to grips with her past by remembering and her father gets on with his life after the Civil War by forgetting. However, Natàlia also attempts to forget, or at least 
momentarily block out, those aspects of the present that she views undesirable, while her father remembers the past as a way of escaping what he perceives to be an unbearable present.

Among those aspects of the present that Natàlia finds most disturbing upon her return is, on the one hand, the demoralized state in which she finds Barcelona, and, on the other hand, the superficial nature of the so-called progress that wealth and modernization have brought to her city (Palerm 187). The first description the narrator provides of Barcelona occurs at the very beginning of the novel when Natàlia makes her way from the airport to her aunt Patrícia's home: "El paisatge era clivellat per cotxes en cementiris, colors grisos i amarronats, motors destrossats, cistelles metàl+liques de l'Hiper, fulles brutes de pols, marges esllavissats, arbres moribunds i l'ermita de Bellvitge engolida per enormes blocs en renglera" (14). The grayishbrown car cemeteries that Natàlia encounters on the outskirts of Barcelona, the dust on dying trees, and row after row of huge apartment blocks serve to reflect the abhorrent social policy of neglect coupled with disastrous urban planning pursued by the city government under the Franco regime. In contrast to the lifelessness that pervades the initial part of the narrator's description of Barcelona in the above passage, the acceleration of life and the increase of wealth that modernization has brought to the city dominate the end of it: "Els cotxes passaven veloços, gairebé a frec del taxi, «ja m’ho han dit: veuràs com hi ha més diners" " (I4-IS). If we contrast this passage with the one I cited earlier in which the narrator describes the interior of her aunt Patrícia's apartment building, we gain a fuller appreciation of Resina's observation cited previously with regards to how objects reflect the era from which they come while also pointing to a new one (235). Whereas the static objects that Natàlia encounters in Patrícia's apartment building recall an earlier period, modernista Barcelona, the speeding cars she witnesses in the passage above signal the arrival of a new epoch, postmodernity. The two passages also differ from one another in that the first one resembles a still frame, while the second appears to be a series of moving frames, thus mimicking film. Sontag aptly describes the paradoxical relationship between photography and film by noting that "a still, which allows one to linger over a single moment as long as one likes, contradicts the very form of film, as a set of photographs that freezes moments in a life or a society contradicts their form, which is a process, a flow of time" (8i). Applying Sontag's observation to the two passages describe above, it could be said that what appears to be the acceleration of time in the second passage contradicts the notion of arrested time in the first, symbolized by a world of still objects.

The contrast between modernity and the emerging postmodern 
era in El temps is further delineated by the novel's focus on two different sectors of Barcelona. Patricia's home, located in the part of Eixample that borders the old part of the city, and Lluís and Silvia's home, positioned at the outer edge of the Eixample, are two important spaces in the topography the novel presents, for each one conjures up a very different period in the history of Barcelona. If the narrator's description of the objects in the interior of Patricia's apartment building evokes the sensuality and originality that characterized the art and architecture of modernista Barcelona, her description of the interior of Lluis and Sílvia's home underscores what Jameson describes as the "flatness or depthlessness" of postmodern artifacts (Postmodernism 9). The following excerpt from the narrator's description of their home serves to illustrate my point: "[L]es reproduccions de Vasarely, Mondrian, Hoyland, Nicholson, línies fredes, colors metàl-lics, grans panys de paret de color blanc, tons apagats" (54). The "cold lines" and "metallic colors" of the reproductions of the works of Northern European artists conjure up the age of mechanical reproduction in which simulacra replace the originality of style and the subjective nature of the content in works of art from an earlier age.

As noted earlier, a clear preference is given to older neighborhoods in El temps.

When Natàlia returns to Barcelona she decides to stay with her aunt Patrícia in the Eixample near the Barri Gòtic, and it is here where Natàlia and Màrius end up after deciding to spend time getting to know one another following Encarna's wedding. As they enter the Barri Gòtic it is as if they had been transported to another epoch: "La pàtina de la història i la vida quotidiana havia cobert els palaus d'una humitat verdosa" (192). Like so many other things the narrator describes in El temps, the physical surroundings in this passage evoke a particular moment in Barcelona's history. In this instance, the physical surroundings recall medieval Barcelona. According to the narrator, it is as if the walls of the noble palaces that Natalia and Màrius pass by drip with history. In fact, the presence of history in the Barri Gotic is so overwhelming that Màrius has the impression he has lived there in another life time. When he mentions this to Natàlia, she quickly reminds him that his great grandparents had lived there all their lives. As they continue to wander about, they stumble upon a moderniststyle sign advertising warehouses where textiles used to be produced. Upon seeing the sign, Natàlia states: "Som de ple a la Barcelona dels nostres avantpassats... els qui van pensar que feien una Barcelona gran, una ciutat important! Tots dos rigueren ${ }^{n}$ (I92). Immediately following her remarks about the city, she and Màrius enter one of the warehouses mentioned above which has been converted into a bar. The description of its interior-the thick velvet curtains, the embossed wooden floor, 
the cornices and molding at the top of each wall, the modernist mirrors with golden frames, the tile floor with a flower motif, and the old spinning tables that have been converted into barroom tables-is clearly meant to evoke both the affluence and the elegant style of modernista Barcelona. Although Natàlia and Màrius find her comment about Barcelona being a "great" and "important city" somewhat humorous, the overall mood of this passage is rather serious. Indeed, their trip to the Barri Gótic ends on a solemn note- a moment that designates an epiphany for Natàlia.

During her time away from Barcelona, she realizes that she always carried the city within her-the same city that had formed and shaped so much of her past. When Màrius threatens to flee Barcelona because he is fed up with his life, and because he believes Barcelona is a city that is slowly sinking into oblivion, Natàlia responds: "[J]o també creia que aquesta ciutat s'enfonsava però a fora he comprès que la ciutat, la portem a dintre" (200). Just as they are finishing their conversation in the early hours of the morning, the narrator interjects and describes the city waking up around them: "Enraonaren molta estona, mentre els sorolls de la ciutat prenien consistència i les boires de la nit desapareixien del tot" (200). The narrative shifts from the Barcelona that Natàlia has internalized to the exterior, or real, Barcelona in which she finds herself. It could be said, then, that her act of "interiorizing" the city becomes a coping mechanism for dealing with the misery and the repression she experiences during the postwar years as a child and adolescent, the disparities she witnesses between Barcelona's working and middle classes as a young adult, and the dramatic changes she observes upon her return to Barcelona as an adult. Moreover, creating an imaginary Barcelona allows her to resolve the contradiction between "una Barcelona gran" that she has heard and read about and which she associates with her forebears, and the decadent Barcelona she has known all her life (r92).

Other characters in the novel also create imaginary worlds in order to escape the unpleasant reality of changes in their lives. Natàlia's mother, Judit, for example, begins to collect objects-all types of porcelain dolls she refers to as fetitxes in honor of her friend Katy, who committed suicide during the war (Bergmann ro2). As a way of coping with the loss of his wife, Joan Miralpeix also begins to collect fetitxesJudit's items of intimate apparel. He eventually becomes delusional and Lluís places him in an insane asylum. Toward the very end of the novel Natàlia discovers her father's whereabouts, which Lluís has kept secret from her, and visits him. The narrator describes the asylum as if it were a microcosm of society, with patients from the bourgeoisie, a work force made up of the working-class patients, a black market, and even an intelligentsia. The doctor who takes Natàlia to her father 
points out a patient who quotes Kant, Schopenhauer, and Nietzsche and is interested in existentialism. In the case of Natàlia's father and his fellow patients, the asylum offers a refuge for those who can no longer cope with the reality of the society in which they live. On one level, reality for them represents those events in the outside world that have marked their lives - the atrocities of the war and the consequences of its aftermath, the onset of an accelerated modernization in Spain during the latter years of the Franco dictatorship, and the loss of a loved one in the case of Natàlia's father. On another level, there exists for them an interior reality, in other words, the worlds they have created within themselves, which underscores their isolation and alienation from the outside world. Moreover, the patient who quotes Kant and Nietzsche highlights the contrast between the philosophical currents behind modernity and postmodernity-Kant representing modernity's focus on the individual as subject and agent in the universe and Nietzsche symbolizing postmodernity's displacement of the individual as such. As Jameson asserts in Postmodernism, "concepts such as anxiety and alienation .... are no longer appropriate in the world of the postmodern" (I4). Natàlia's father and his fellow patients must therefore represent only a microcosm of the society depicted in El temps. Moreover, this microcosm must be removed and shut away from the outside world, for the patients' very feelings of anxiety and isolation would, in the "real world," denote the existence of a subject capable of feeling and experiencing reality outside himself. According to Jameson, however, in the postmodern world the bourgeois subject disappears, or at best it exhibits an extremely fragmented psyche that has replaced the alienated psyche associated with modernism (Postmodernism I4). In light of Jameson's observation, Natalia's father's confinement to an asylum might be understood as a means of preserving the alienated subject vis-à-vis an emerging postmodern world that threatens to splinter that subject to the point where, for all practical purposes, it no longer exists. Like her father, Natallia attempts to safeguard the city she loves against the effects of time by interiorizing it. Unlike her father, however, she cannot completely deny the present and therefore must confront the emerging postmodern reality that surrounds her.

With El temps Montserrat Roig responded to the transformations that took place in Catalan society during the latter half of the twentieth century by looking to Catalunya's past in order to educate a younger generation of Catalans who had had little exposure, if any at all, to their cultural heritage. Furthermore, she employed the motifs of photography and time in this novel to capture and document those transformations, as well as the more remote past. In the essay on Proust cited earlier, Brassaï states: "The passage of time in itself does 
not interest Proust. Moreover, he never speaks of cinematic views, but only of snapshots. A man of discontinuity, Proust is a photographer, not a filmmaker" (I05). Like Proust, Roig too was interested in snapshots - snapshots that depicted Catalan society, past and present. In a 1984 interview with Geraldine Nichols, Roig stated, "Y es a partir del Ensanche - que es mi mito-que he podido observar un mundo en descomposición, unos ciertos cambios de valores. Y que el tiempo es irrecuperable" (Escribir $17 \mathrm{I}$ ). Roig thus conceded that time past cannot be recovered in a literal sense; however, she does recognize that it can be recorded through memory and through the photographic-like description of one's surroundings, and this is what she managed to do in El temps. Like her character Natàlia, who internalizes the city she loves, Roig, in the wake of Franco's death, imagined the city she loved, especially the area of the Eixample, by fictionalizing it in order to recapture its former splendor and present it to a younger generation as a signpost for the reconstruction of a new Barcelona in a fledgling democratic Spain. Natàlia, Roig's creation, embodies the nostalgia that Roig herself, and by extension the Catalan community, felt with regards to Barcelona's past. However, as noted previously, Natàlia also chose to confront the present. Like Natàlia, Roig, despite romanticizing aspects of Barcelona's past, began to grapple with some of the significant social changes the city had undergone by the late 1970s. She did so by skillfully weaving together the motifs of photography and time in El temps. Perhaps the following observation by Sontag best reflects the impact of Roig's decision to employ these motifs in her novel: "As photographs give people an imaginary possession of the past that is unreal, they also help people take possession of space in which they are insecure" (9). Indeed, Montserrat Roig's El temps helped Catalans navigate the uncharted waters in which they found themselves following Francisco Franco's death.

\section{ANDREW J. DEISER UNIVERSITY OF ARKANSAS, LITTLE ROCK}

\section{WORKS CITED}

BergmanN, Emilie L. "Mothers, Daughters, and the Mother Tongue: Martín Gaite's El cuarto de atrás and Roig's El temps de les cireres." Multicultural Iberia; Language, Literature, and Music. Ed. Dru Dougherty and Milton M. Azevedo. Berkley: IAS, 1999. 93-108. Brassai, [Gyula Halász]. Proust in the Power of Photography. Trans. Richard Howard. Chicago: U of Chicago P, 2001. 
DUPLÁA, Christina. "Historia del avance espacial de Barcelona y sus mujeres. Ideología y estética de la ciudad en Montserrat Roig." Confluencia $\mathrm{r}_{3}$ (1998): 40-47.

- "Montserrat Roig: Women, Genealogy, and Mother Tongue." Trans. H. Patsy Boyer. Recovering Spain's Feminist Tradition. Ed. Lisa Vollendorf. New York: $M L A$, 2001. 337-56.

GULLóN, Germán. "La fotografía en la novela; Alarcón, J. Goytisolo, Benet. Insula. 42: (1, 10), 1987.

JAMESON, Fredric. Postmodernism or, the Cultural Logic of Late Capitialism. 1991. $9^{\text {th }}$ ed. Durham: Duke UP, 2001.

NiCHOLS, Geraldine. Escribir, espacio propio: Laforet, Matute, Moix, Tusquets, Riera y Roig por si mismas. Literature and Human Rights 7. Minneapolis: Institute for the Study of Ideologies and Literature, 1989.

- "Montserrat Roig (1946-1991)." Spanish Women Writers: A BioBibliographical Source Book. Ed. Linda Gould Levine, et al. Westport CT: Greenwood, 429-40.

PALERM, Carmiña. "Memory, Oblivion and Space: The Art of Memory in Montserrat Roig's Tiempo de cerezas." Visión de la narrativa bispánica. Ed. Juan Cruz Mendizábal and Juan Fernández Jiménez. Indiana, PA: IUP, 1999. 179-91.

ResinA, Joan Ramon. "The Link in Consciousness: Time and Community in Rodoreda's La Plaça del Diamant." Catalan Review 2.2 (1987): $225-46$.

RoIG, Montserrat. El temps de les cireres. 1977. Ed. Carme Arnau. $3^{\text {rd }}$ ed. Barcelona: Edicions 62, 1998.

SoNTAG, Susan. On Photography, 1973. New York: Picador, 1977. 